\title{
Gender Equality in Vietnam, Issues Raised
}

\author{
Vu Thi Hien, Ho Ngoc Anh \\ University of Transport and Communications (UTC), Vietnam
}

DOI $<$ 10.26821/IJSRC.8.3.2020.8305>

\begin{abstract}
Gender equality is a big issue, always given special priority by the State of the Socialist Republic of Vietnam. Over the past years, Vietnam's efforts to implement gender equality have brought about great achievements and recognized and appreciated by the international community. However, besides the results, there are still many shortcomings, limitations need more attention of the government, the participation of the entire population to overcome the limitations and inadequacies. This study focuses on analyzing the achievements and limitations of gender equality issues in Vietnam, thereby proposing solutions to better implement gender equality issues.

Keywords: Gender equality, government of Vietnam, value men above women
\end{abstract}

\section{INTRODUCTION}

Gender equality is one of the basic rights and obligations of Vietnamese citizens, which is specified in legal documents and international conventions to which Vietnam has signed. According to Clause 3, Article 5 of the Law on Gender Equality (2006): "Gender equality means that men and women have an equal position and role, are given opportunities and be facilitated to promote their capacity for the development of the community, the family and enjoy the same in the fruits of that development".

It can be said that gender equality goals are the top concern of nations in particular and the international community in general. As early as 1955, the United Nations unanimously agreed and adopted the Gender Action Program, gender mainstreaming at the Fourth International Conference on Women, in Beijing (China) (1979), it continued to ratify the International Convention to Eliminate all Forms of Discrimination against Women and the third-millennium goal was also to promote gender equality and the empowerment of women. The UN General Assembly (1977) also decided to set many international holidays, many important events for the sake of gender equality, and for the advancement of women. This shows the special priority of the international community on gender equality.

Vietnam is one of the countries that soon give priority to gender equality. Specifically, in the first Constitution of the Democratic Republic of Vietnam (1946), Article 9 referred directly to the equality of men and women: "Women are equal to men in all aspects". President Ho Chi Minh in the will (1968), he also pondered the role and position of women: "The Party and the Government need to have practical plans to foster, remind and help to more and more 
Volume 8 Issue 3 March 2020

women in all jobs, including leadership. Women themselves must strive to rise. It is a revolution that brings real equality to women". This issue has been institutionalized into legal documents such as the Law on Gender Equality (2006), the Law on Domestic Violence Prevention (2007) and control, or the promulgation of action programs such as the National Program of Action on Equality in the 2016-2020 period, the National Program of Action on Domestic Violence Prevention and Control to (2020), etc. to ensure the rights of women in the fields of politics, economy, labor, education, and health and position in their own family.

\section{ACHIEVEMENTS AND LIMITATIONS IN GENDER EQUALITY ISSUES IN VIETNAM}

Over the years, the Government of Vietnam has strived to bring real gender equality to the people of Vietnam, so that the people of Vietnam can truly live in a civilized society, sustainable development, and humanity. Although there are still some limitations in the implementation of the Party's policies, the State laws and policies on gender equality such as gender inequality also appear in some important fields of social, women still bear many burdens of work, income, and discrimination. Women's participation in organizational structure and social management is limited, especially at the grassroots level. In some places, the income gap between men and women remains the same in the same job position, the opportunity for women to access highincome jobs is still lower than that for men and women workers (UN Women., 2016). Female workers are not appreciated as male workers, which is more vulnerable when the enterprise needs to reduce manpower. Violence against women still occurs in some places, especially in rural and remote mountainous areas. However, it can be said that Vietnam is one of the countries with many achievements in the implementation of gender equality, making an important contribution to the country's development in the integration period.

In the field of politics: Vietnam is one of the nation's remove gender gap the fastest in the past 20 years (Un Women., 2016), already ahead of schedule for the goal of equality between men and women and improving status for women (this is one of the Millennium Development Goals we strive to achieve) (The Government of the Socialist Republic of Vietnam. 2017). Vietnam is considered by the United Nations to be a bright spot in achieving the millennium goals, one of the countries with high gender equality achievements. According to the ranking of the United Nations (2012) in the index of gender inequality, Vietnam ranked 47/187 countries, compared to ranked 58/136 countries in 2010 (the closer the 0 is, shows the more the equality high). The percentage of female delegates accounted for over $25 \%$ (from IXth term to XII term of Party) and the results of the XIV (2016 -2021) National Assembly deputies term with the percentage of female deputies in the XIV National Assembly was $26.72 \%$, increasing $2.62 \%$ compared to the previous term, making Vietnam one of the countries with the highest proportion of female National Assembly deputies in the region and the world (ranked 43/143 countries in the world and 2nd in Asia in terms of The percentage of women in the National Assembly (higher than China, South Korea, and Japan, etc.) and also the first time Vietnam has a female National Assembly Chairman. Although it has not met the requirements of reality, the percentage of 
Volume 8 Issue 3 March 2020

women is large. Provincial People's Council term of 2016-2021 reached 26.54\% (up $1.37 \%$ ); district-level reached $27.85 \%$ (up $3.23 \%$ ) and commune level reached $26.59 \%$ (increased 4, 88\%). "As of June 2017, in Vietnam, the male has $12 / 30$ Ministries, Ministerial-level agencies, and governmentattached agencies with women in charge of leading positions, reaching $40 \%$, including 10/22 Ministries, Ministerial-level agencies and 02 / 08 Government agencies" (The Government of the Socialist Republic of Vietnam. 2017).

In the field of economics and labor: In 2016 alone, Government was created for about 1,641 million workers, of which female workers accounted for $48 \%$. This indicator exceeded $8 \%$ compared to the target set in the National Strategy on gender equality for the period 2011-2020. "According to the General Statistics Office, as of July 1, 2017, the labor force aged 15 and over was estimated at 54.5 million, of which male workers 28.3 million accounted for $52 \%$, female workers 26.2 million, accoüting for $48 \% "$ (The Government of the Socialist Republic of Vietnam. 2017). "In 2016, 10 localities reached the percentage of women owning a business from $30 \%$ or more. Particularly for Binh Duong, the percentage of women participating in the leadership of state enterprises reaches 50\%" (The Government of the Socialist Republic of Vietnam. 2017). In the period 2010-2015, the number of female workers moving out of the agricultural sector was higher than that of male workers. "If in 2010, the proportion of women and men employed in agriculture was $51.2 \%$ and $46.4 \%$ respectively; by 2015 , these rates have decreased to $45.5 \%$ and $42.7 \%$, respectively "(UN Women. 2016). Vocational training and job creation for female workers, especially in rural areas, were focused, with an estimated $46 \%$ of female workers receiving vocational training under the policies of the Project on vocational training for workers in the countryside; over $40 \%$ of female workers will get jobs. In addition, women's economic rights have been enhanced through the provision of women in the name of men in their certificates of ownership of land, houses, and properties. Improved access to women's credit ((The Government of the Socialist Republic of Vietnam. 2017).

In the field of health, culture - education and science and technology: Vietnam is also a leading country in the Asia-Pacific region in terms of gender equality indicators through the provision of health services, education for girls, boys, and women. The illiteracy rate of women compared to men is decreasing (Ministry of Education and Training. 2017). These are very significant numbers because the implementation of gender equality will help bring great resources for the sustainable development of each country.

Prevention of mother-to-child transmission is now being implemented nationwide with new directions for mother-to-child transmission interventions. The achieved results are as follows: "The percentage of pregnant women receiving preventive treatment that helps reduce mother-to-child HIV transmission is $55.7 \%$, the percentage of children born to HIV-infected mothers being tested for HIV within 02 months after birth reached $48.4 \%$, the estimated percentage of HIV-infected children born to HIV-infected mothers in the past 12 months was 12.4\%" (The Government of the Socialist Republic of Vietnam. 2017). The above results show that Vietnam's health sector has continuously made efforts to effectively implement the 
Volume 8 Issue 3 March 2020

goal of stopping and repelling the spread of the HIV/AIDS epidemic (one of the 4 MDGs on health).

Culture is the foundation for people to participate and exercise their civil rights. From the first Constitution (1946) to the Constitution of the State of Vietnam (2013), all affirmed that Study is a right and a duty of citizens. With the motto, education is a top national policy, the national education system has been built relatively complete and unified; expand the scale and initially diversify training types and modes, creating many opportunities for people including women to study. More and more collectives and individuals of female scientists who have researched works have received VIFOTEC awards from the Vietnam Union of Science and Technology Associations, the Creative Labor Certificate of the Vietnam General Confederation of Labor, Vietnam Women's Union, Vietnam Women's Award, KosoyoKai-A, etc. Many female scientists have established career associations, clubs and research centers to continue promoting the intelligence and talents to contribute to the development of the country.

In addition to the above-mentioned achievements, gender equality in recent years still has some limitations such as a number of Party policies and laws of the State on gender equality that have not yet been thoroughly applied in real-life (UN Women. 2016). The attention of the Party committees and authorities in some localities, ministries, and branches (especially the head) is not really close. Therefore gender equality activities are still formal and not yet achieved be the desired effect. The Party and State's propaganda and campaign on gender equality have not been really effective. The implementation of gender equality in specific areas is still limited. Gender stereotypes still exist, causing difficulties in implementing policies and laws on gender equality in localities and grassroots levels. The contingent of officials working on gender equality is still small (especially in localities) so it has not really brought into play the role of state management agencies in participating in the evaluation of mainstreaming gender equality issues.

\section{SOLUTIONS TO IMPLEMENT GENDER EQUALITY GOALS IN VIETNAM TODAY}

Firstly, raising awareness about gender equality of the whole society. Empowering Vietnamese women is an objective requirement of national development. It also stems from a request to fulfill the responsibility of the state is a member of the UN before the international community and the region. It is also a content of bringing the Party's guidelines and policies, the laws of the State on gender equality and the empowerment of women in real life.

Secondly, it is necessary to grasp five basic views including) To achieve the goal of gender equality and empower women must be based knowledge on gender equality and women's empowerment; ii) Implementation of the goal of gender equality and women's empowerment is to promote the role and great potential of women in the cause of national renewal, empowering women and achieving gender equality in all areas; iii) To achieve the goal of gender equality and the empowerment of women must be associated with building the rule of law state of the people, by the people and for the people, and promoting socialist democracy; iv) Achieving gender equality and women's 
Volume 8 Issue 3 March 2020

empowerment can only be successful when it comes to resolving against the idea of "respect men and disdain women" and discriminate against women; v) The goal of gender equality and the empowerment of women requires promoting the role and responsibility of both the political system, the whole society, and each family in ensuring women's rights.

Thirdly, promoting education activities to raise the awareness of leaders, society, families, and women about the rights of women, in which attaching importance to regular training on gender and equality gender and rights for women leaders of departments, unions, Women's Union officials at all levels. Continue to integrate gender and gender equality and women's rights into the training program for intermediate and senior officials. In particular, attention should be paid to integrating gender equality issues with specific guarantees of women's rights into local socio-economic activities in training courses for local officials, contribüting part of improving knowledge and skills to implement gender equality promotion measures for leaders and managers so that they can integrate gender policies into socioeconomic programs in locally more effective.

Fourthly, continue to improve policies and laws on ensuring women's rights: full and timely legalization of international standards on women's rights in the international treaties that Vietnam has joined. Review, amend and supplement regulations related to gender equality and women's empowerment, overcome constraints and institutional barriers. Pay attention to building specific institutions to ensure women's rights as particularly difficult circumstances such as rural women and ethnic minority women as required by the CEDAW Convention to create a legal basis for Vietnamese women to access and enjoy rights of women.

\section{CONCLUSION}

The XXI century has promoted the role of women, which requires women to constantly study and train to improve the role and appreciation of society. Currently, women participate in almost all areas of social life but women are not allowed to forget the responsibility to fulfill the role of the mother and wife in the family. Every woman must always have a sense of cultivating the four virtues of Cong (skillful of work) - Dung (a pretty face) - Ngon(soft speech) - Hanh (gentle temperament). Must fulfill the role of motherhood, have the responsibility to nurture and educate children to grow up. Women are also first teachers of children, treating them fairly and equality.

In fact, if women try to achieve many successes in life and career, they have become a great source of encouragement and encouragement for their sisters, daughters in the family and for female colleagues in agencies and mass organizations so that they can firmly and confidently strive to rise up.

Thus, it can be seen that gender equality is a matter of special priority by the Vietnamese Government. And efforts in the implementation of gender equality have brought about great achievements recognized and appreciated by the international community. However, besides the obvious results, there are undeniable limitations and shortcomings. But it must be affirmed again: Gender equality, ethnic equality becomes the development goal of Vietnam in particular, of the international community in general. To achieve this goal is not a simple matter, but a long process and requires the participation of 
Volume 8 Issue 3 March 2020

the government, the participation of the entire people.

\section{ACKNOWLEDGMENTS}

Our thanks to the experts who have contributed towards development of the template.

\section{REFERENCES}

[1] Communist Party of Vietnam, Document of the 11th National Assembly. Hanoi: National politics. Hanoi: Politics - Truth, 2011

[2] Communist Party of Vietnam, Document of the 12th National Assembly. Hanoi: National politics.Hanoi: Politics - Truth, 2016.

[3] Joint cooperation program between the Government of Vietnam and the United Nations on Gender Equality, The current system of legal documents on gender equality and prevention of domestic violence. Hanoi: Thoi Dai, 2011.

[4] National Assembly of the Socialist Republic of Vietnam. (2006). Gender equality law. Hanoi: National Politics. Hanoi: Politics - Truth.

[5] The Government of the Socialist Republic of Vietnam, National report on results for 15 years of implementation millennium goals of Vietnam.Hanoi: Politics - Truth, 2015.

[6] The Government of the Socialist Republic of Vietnam, Draft report on the implementation of national goals on gender equality in 2016 and the first 6 months of 2017.Hanoi: Politics - Truth, 2017.

[7] The Government of the Socialist Republic of Vietnam, Report No. 377/BC-CP dated September 12, 2018 of the Government on the implementation of the National Goal on gender equality in 2017, 2018 [8] UN Women (United Nations Agency for Gender Equality and Empowerment of Women in Vietnam) and Department of Gender Equality (Ministry of Labor, War Invalids and Social Affairs), Practice and data on women and men in Vietnam 2010 $-$
2015 , 2016. 